Review article

\title{
Audiovisual feedback device use by health care professionals during CPR: A systematic review and meta-analysis of randomised and non-randomised trials
}

\author{
Shelley Kirkbright ${ }^{\mathrm{a}, *}$, Judith Finn ${ }^{\mathrm{a}, \mathrm{b}, \mathrm{c}}$, Hideo Tohira ${ }^{\mathrm{b}}$, Alexandra Bremner ${ }^{\mathrm{a}}$, \\ Ian Jacobs ${ }^{\mathrm{a}, \mathrm{b}}$, Antonio Celenza ${ }^{\mathrm{a}}$ \\ a University of Western Australia, Australia \\ b Curtin University, Perth, Australia \\ c Monash University, Melbourne, Australia
}

\section{A R T I C L E I N F O}

\section{Article history:}

Received 14 September 2013

Received in revised form 30 October 2013

Accepted 9 December 2013

\section{Keywords:}

Cardiopulmonary resuscitation

Cardiac arrest

Feedback device

\begin{abstract}
A B S T R A C T
Objectives: A systematic appraisal of the literature to determine if audiovisual feedback devices can improve CPR quality delivered by health care practitioners (HCPs) and/or survival outcomes following cardiac arrest.

Methods: We searched the Cochrane Central Register of Controlled Studies (CENTRAL) on The Cochrane Library, MEDLINE, EMBASE, CIHAHL and AUSTHEALTH in May 2013 for experimental and observational (human or manikin) studies examining the effect of the use of audiovisual feedback devices by HCPs in simulated and actual cardiac arrest. The primary outcome for human studies was survival to hospital discharge with good neurologic outcome. Secondary outcomes were other survival data and quality of CPR performance; the latter was also reported for manikin studies.

Results: Three human interventional studies $(n=2100)$ and 17 manikin studies met the inclusion criteria. Overall quality of included studies was poor, with significant clinical heterogeneity. All three human studies reported no significant change to any survival outcomes despite improvement in chest compression (CC) depth by $2.5 \mathrm{~mm}$ (95\% CI 0.9-4.3), CC rate $6 \mathrm{~min}^{-1}$ closer to 100 (95\% CI 2.4-10.7) and a reduction in no-flow fraction by $1.9 \%$ on meta-analysis. Manikin studies showed similar improvements in CC parameters.

Conclusion: In both manikin and human studies, feedback during resuscitation can result in rescuers providing CC parameters closer to recommendations. There is no evidence that this translates into improved patient outcomes. The reason for this is not yet evident and further patient centered research is warranted.
\end{abstract}

\section{Contents}

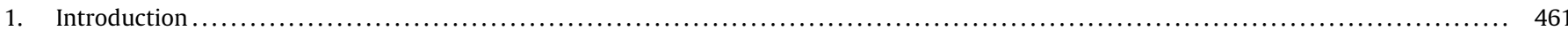

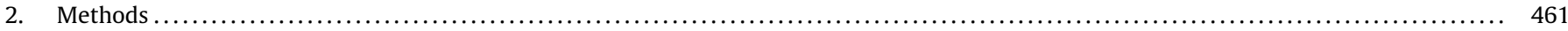

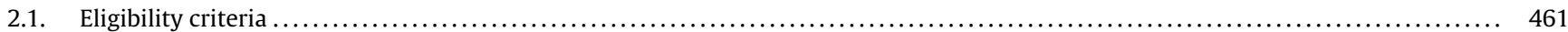

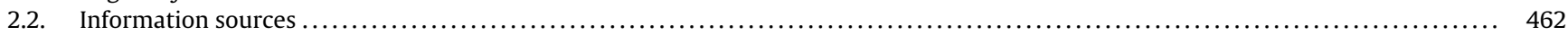

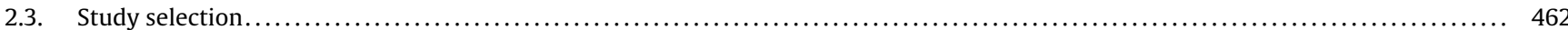

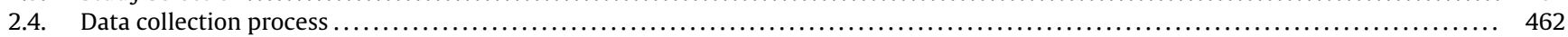

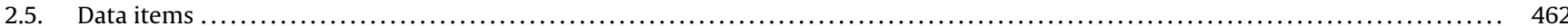

2.6. Assessment of risk of bias in individual studies . . . .

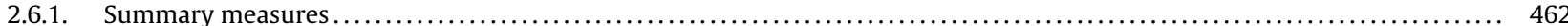

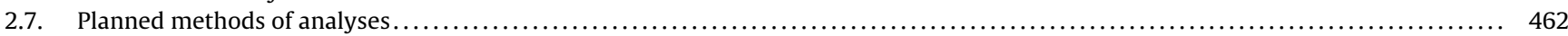

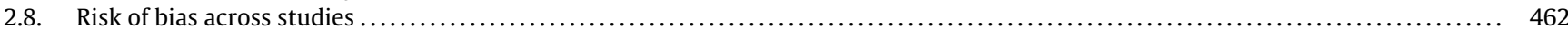

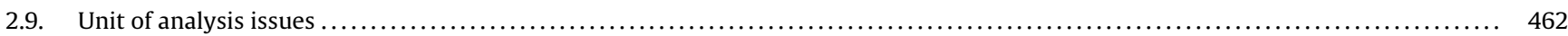

\footnotetext{
* Corresponding author.

E-mail addresses: shelley.kirkbright@uwa.edu.au, shelleykirkbright@gmail.com (S. Kirkbright).
} 


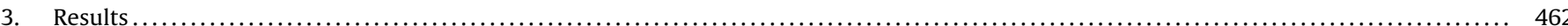

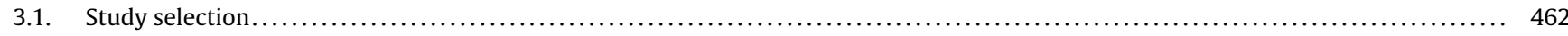

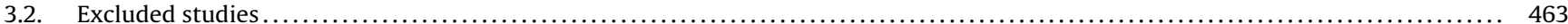

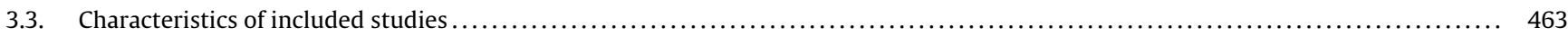

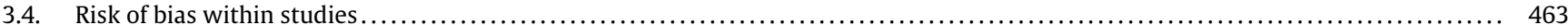

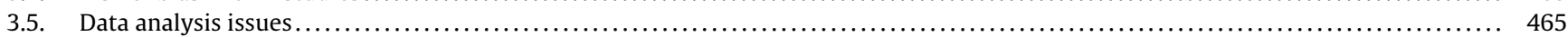

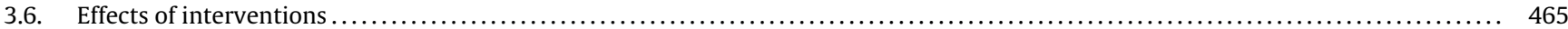

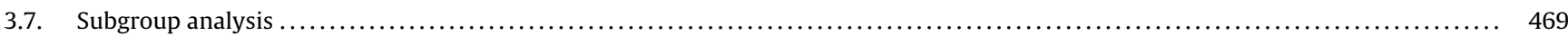

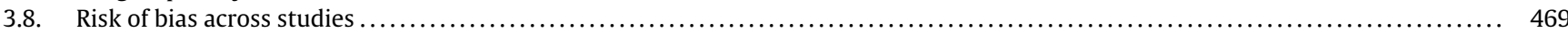

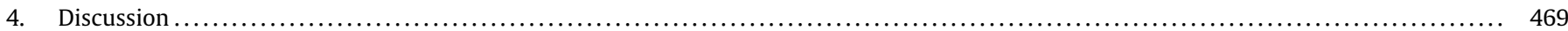

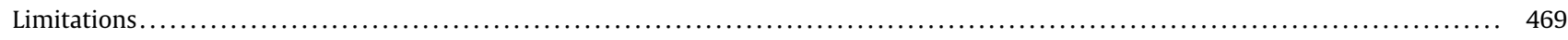

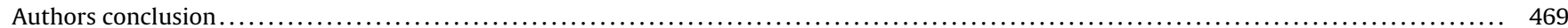

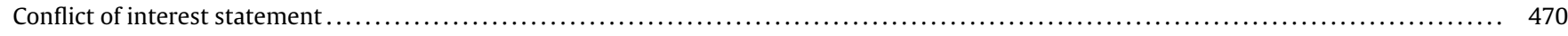

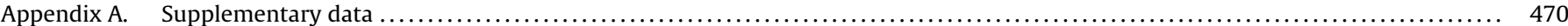

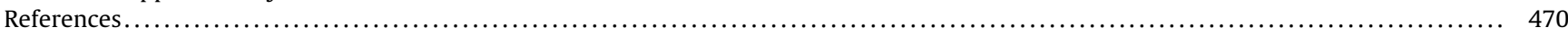

\section{Introduction}

Out-of-hospital cardiac arrest (OHCA) is a major public health problem with over $90 \%$ case fatality. ${ }^{1}$ Global incidence of adult OHCA is estimated at 95.9 per 100,000 person-years. $^{2}$ Survival to hospital discharge is poor, although it has been shown to vary widely between different emergency systems in the US. ${ }^{3}$

The 2010 International Liaison Committee on Resuscitation (ILCOR) consensus guidelines ${ }^{4}$ reiterate the importance of optimising all links in the "Chain of Survival' ${ }^{5}$ to maximise neurologically intact survival after cardiac arrest. This includes the delivery of high quality CPR. Specifically rescuers should: push hard to a depth of at least $5 \mathrm{~cm}$ at a rate of at least 100 compressions per minute, allow full recoil of the chest in between compressions and minimise interruptions in chest compressions (CCs) with a compression to ventilation ratio of $30: 2 .^{6}$ Relatively brief interruptions to CC of even $4 \mathrm{~s}$ duration, lead to reduced myocardial perfusion ${ }^{7}$ and survival. ${ }^{8}$ Furthermore, the success of defibrillation decreases in patients during prolonged periods without $\mathrm{CC} .{ }^{9} \mathrm{CC}$ depth and fraction (the proportion of time CCs are administered in CPR) are directly related to survival from OHCA. Every $1 \mathrm{~mm}$ increase in depth (up to $50 \mathrm{~mm}$ ) increases the adjusted odds of survival by $5 \%$ (OR 1.05, 95\% CI 1.01-1.09). ${ }^{10}$ High CC fractions (>60\%) are associated with higher rates of return of spontaneous circulation (ROSC) ( $79 \%$ vs. $58 \%$ ) and survival to discharge (25\% vs. $12 \%)$ when compared with the lowest fraction group $(<20 \%) .{ }^{11}$

Although it is known that good quality CPR leads to improved patient outcomes, health care practitioners commonly perform sub-optimal $\mathrm{CPR}^{10,12-15}$ with as little as $28 \%$ of CC in the target depth range, effective compression rates as low as 64 per minute and a hands off fraction of $0.48 .{ }^{12}$ Real-time feedback may enable rescuers to perform better CPR, which may translate into improved patient outcomes. The only systematic review of the impact of realtime feedback during $\mathrm{CPR}^{13}$ was completed in 2009 and focused on feedback as a training device rather than an adjunct to real-life cardiac arrests. The authors concluded that there was good evidence supporting the use of feedback devices in CPR training to improve skill acquisition and retention. ${ }^{13}$ However, a beneficial effect on patient outcomes has yet to be established. As several individual studies $^{16-23}$ have been published since the original review, it is time to review the evidence with a focus on the effect of the use of real-time feedback to improve the quality of CPR in the 'real' cardiac arrest episode.

Objectives: Our systematic review of interventional and observational studies seeks to address the questions "Does the use of feedback devices improve the quality of CPR performed by health care professionals when training on manikins compared to no device? Does the use of feedback devices improve patient outcomes (ROSC, survival to hospital discharge and neurologically intact survival) and quality of CPR parameters in cardiac arrests compared to no device?"

\section{Methods}

Protocol registration: PROSPERO registration number CRD42012003064. ${ }^{24}$

\subsection{Eligibility criteria}

Participants: CPR providers must be health care practitioners (HCPs) or HCP students, defined as people whose primary role is the provision of health care. Subjects may be manikins to address the outcome of CPR quality (hitherto referred to as the 'manikin studies') or humans experiencing a cardiac arrest to address both outcomes of CPR quality and survival (hitherto referred to as the 'human studies'). The cardiac arrest may occur in the in-hospital or out-of-hospital setting.

Interventions: Any study measuring CPR quality using a monitor that detects chest wall movement and, as a minimum, can quantify rate or depth of CCs was considered for inclusion. As the primary objective of our review was to determine if the use of feedback devices is able to improve actual CPR performance and/or outcome from cardiac arrest, rather than a teaching tool to improve skill acquisition, it was decided that the feedback device must be in use at the time of cardiac arrest or arrest simulation. Manikin studies that investigated the effect of feedback during training only, but not at the time of simulated resuscitation testing, and human studies that provided delayed feedback in the form of debriefing or performance evaluation were both excluded. Studies investigating the use of timing devices and metronomes that did not change or give feedback depending on the quality of CPR detected were also excluded.

Comparison: The intervention (real-time use of CPR feedback device) was compared to the comparison group of CPR performed without the use of the device.

Outcomes: The primary outcome for human studies was patient survival to hospital discharge with good neurological outcome. Secondary outcomes in human studies included other patient survival data (ROSC, alive (spontaneous circulation) on arrival to emergency department, survival to hospital discharge). For human and manikin studies, markers of improved CPR were abstracted: CC rate, CC depth, and proportion of time without CPR (no-flow fraction). We also collected data on adverse effects and user satisfaction with the devices.

Types of studies: Published original research articles on randomised and non-randomised interventional studies, as well as observational studies with a comparator group were included. No 
publication date or language restrictions were imposed. Animal studies, case studies, reviews and opinion pieces were excluded.

\subsection{Information sources}

Electronic searches:

- Cochrane Central Register of Controlled Studies (CENTRAL) on The Cochrane Library (Issue 2012)

- MEDLINE using Ovid platform (1946 to 16/05/2013)

- EMBASE (1980 to 16/05/2013)

- CINAHL (1998 to 16/05/2013)

- AUSTHEALTH (1997 to 16/05/2013)

The Medline search strategy is in Appendix 1.

Searching other resources: The reference lists from included studies and review articles were searched for additional papers. Experts in the field and representatives from Laerdal, manufacturer of CPR quality and feedback monitoring device Q-CPR, were contacted for knowledge of published studies on the topic.

\subsection{Study selection}

Authors used pre-defined inclusion criteria to decide on the status of each citation. Two authors (SK and JF) screened citations in an independent, hierarchical fashion by title, abstract and then full article for relevance. At each stage of review citations were classified as "include", "exclude" or "indeterminate". Titles and abstracts with clearly unrelated content were discarded. Citations marked as "include" or "indeterminate" by either of the reviewers were included in the next level of review. Disagreements at the full article stage were resolved though consensus with the assistance of a third reviewer (IJ). Agreement between authors at each stage was quantified using a kappa statistic. A record was kept of all studies excluded at the full text stage, along with the reason.

\subsection{Data collection process}

One reviewer (SK) extracted the following data from included studies and the second author (JF) checked the extracted data, and discrepancies were resolved through consensus.

\subsection{Data items}

Information was extracted from each included trial on: (1) characteristics of trial participants (including age, sex); (2) arrest or simulated arrest details (OHCA/in-hospital-cardiac-arrest (IHCA), manikin, 2 person/1 person resuscitation, resuscitation guidelines in place); (3) study design including inclusion and exclusion criteria; (4) type of feedback device used; and (5) type of outcome measure (ROSC, survival outcomes, CPR quality measures, user satisfaction and adverse outcomes).

\subsection{Assessment of risk of bias in individual studies}

One author (SK) evaluated each included study for risk of bias. As recommended by the STROBE statement ${ }^{25}$ and The Cochrane Handbook for Systematic Reviews of Interventions v5.1.0, ${ }^{26}$ the randomised trials were evaluated for selection bias, performance bias, attrition bias and detection bias.

Quality of non-randomised trials was assessed using the Newcastle-Ottawa Scale (NOS), ${ }^{27}$ a 'star based' scoring system which judges studies on three broad perspectives: the selection of the study groups, the comparability of the groups, and the ascertainment of either the exposure or outcome of interest for case-control or cohort studies respectively. Missing data were documented as part of study quality assessment.

\subsubsection{Summary measures}

Survival to hospital discharge with good neurologic outcome was the primary measure of treatment effect for the human studies. The meta-analyses were performed by computing odds-ratios (ORs) and 95\% confidence intervals (CIs) using random-effects models for each survival outcome. Secondary outcomes were CC depth, $\mathrm{CC}$ rate and no-flow fraction (NFF), and meta-analyses of these outcomes were performed by computing mean differences and 95\% CIs using random-effects models. P-values $<0.05$ were considered significant.

\subsection{Planned methods of analyses}

Inconsistency (the percentage of total variation across studies due to heterogeneity) of effects across feedback devices was measured using the Breslow-Day test performed by Review Manager RevMan Version 5.2. ${ }^{28}$ The advantages of this measure of inconsistency (termed $I^{2}$ ) are that it does not inherently depend on the number of studies and can be interpreted similarly irrespective of the type of outcome data (dichotomous or continuous). ${ }^{29}$ Metaanalysis was not performed when $I^{2}>75 \%{ }^{30}$

The heterogeneity between studies was explored qualitatively with thorough scrutiny of included studies for clinically relevant differences. A priori subgroup analysis was planned to address clinical heterogeneity. Subgroups identified included human/manikin studies, adult/paediatric studies, OHCA/IHCA studies and device used (CPREzy, QCPR, ZOLL, VAM, Heartstart 4000SP). We planned to conduct sensitivity analyses that included removal of data from studies assessed to be at moderate or high risk of bias during quality review.

For randomised cross-over (manikin) trials, only first stage data were used in meta-analyses to minimise bias introduced from a learning effect. For example, when a group randomised to perform CPR with the aid of a device in stage 1 and without the device in stage 2 was compared to a group that performed CPR without the device in stage 1 and with it in stage 2, only first stage data were included.

\subsection{Risk of bias across studies}

We assessed publication bias by evaluating funnel plots of the study. We acknowledge that asymmetry may also be produced by factors such as differences in study quality and heterogeneity. ${ }^{29}$

\subsection{Unit of analysis issues}

CC depths reported in inches were converted to centimeters. No-flow times, CC fraction and CC times were converted into NFF using the overall CPR time period. For example, NFF was calculated from one minus CC fraction, one minus CC time divided by total CPR time or no-flow time divided by total CPR time.

\section{Results}

\subsection{Study selection}

The comprehensive search identified 2959 citations (Medline 1697, EMBASE 670, AUSTHealth 8, CINAHL Plus 517, Cochrane CENTRAL 64, hand search of included papers and review article references 3). SK reviewed 2959 citations by title; 97 of these were categorised as "include" or "indeterminate" and were selected for review by abstract. Two authors (SK and JF) independently 


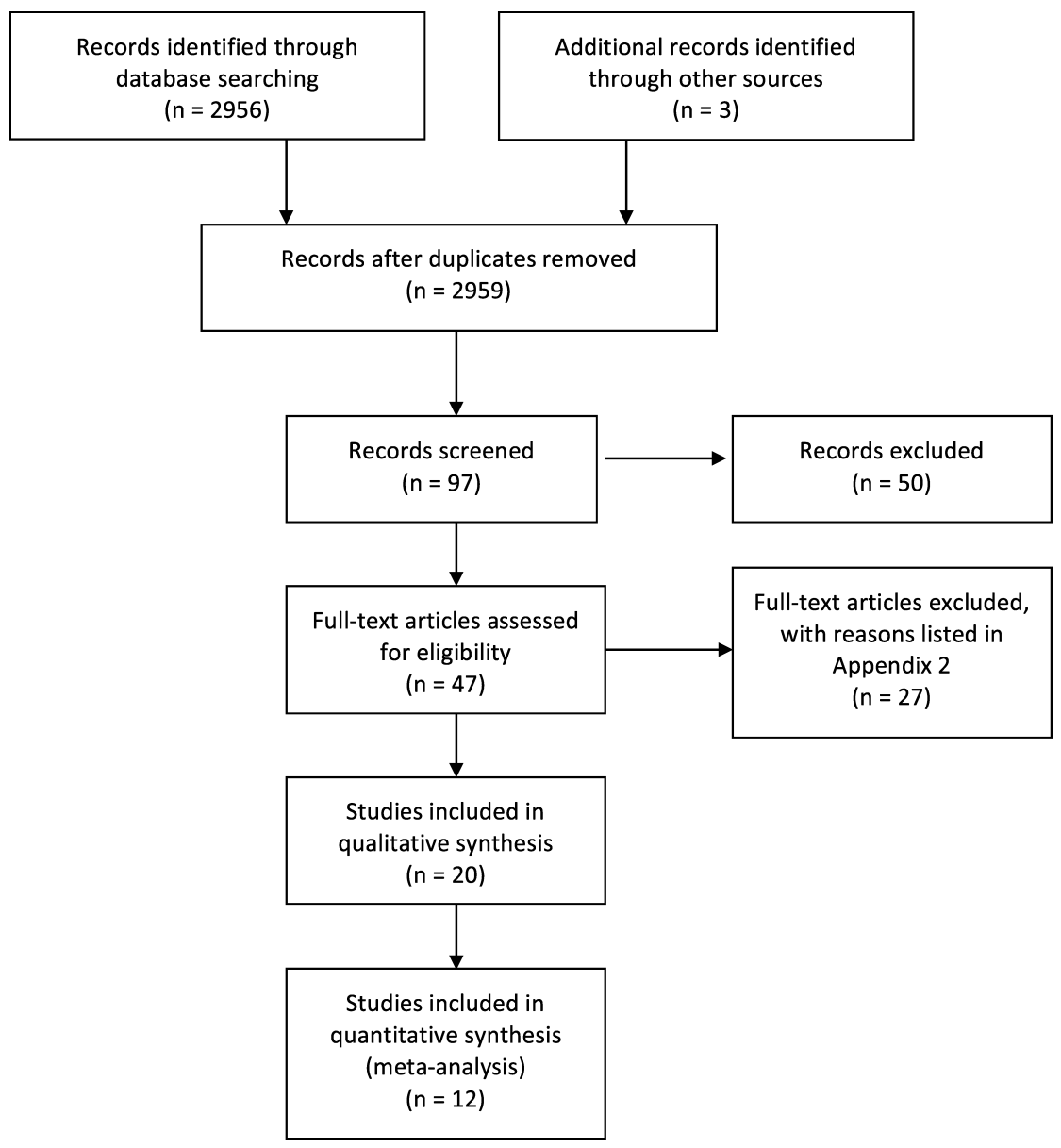

Fig. 1. PRISMA flow diagram.

reviewed these abstracts and identified 48 potentially relevant citations to be reviewed by full article of which 20 met all inclusion criteria and were included in this review. There was very good agreement for abstracts (kappa 0.915) and full agreement (kappa 1.0) at full article stage. Twenty-seven citations reviewed by full article were excluded. One study ${ }^{17}$ that had been presented at a conference could not be included, as we could not get the full article despite several attempts to contact the authors. The process is detailed in a PRISMA flow diagram (Fig. 1).

\subsection{Excluded studies}

Common reasons for exclusions were: (1) that the article described an experiment involving the use of feedback mechanism either before or after the CPR event, for example, post event debriefing, rather than any real-time feedback whilst performing CPR, (2) that the study population performing CPR was mainly or entirely a layperson population, and (3) that the main study outcomes were not CPR quality variables or patient outcomes. Full details are in Appendix 2.

\subsection{Characteristics of included studies}

All included studies were published in English between 1995 and 2012. Most studies were conducted in Europe (60\%) and North America (35\%). Of the three studies in humans, all were conducted on adults, two included only OHCA ${ }^{10,16}$ and one only IHCA. ${ }^{31}$ There are no relevant published individually randomised controlled trials on humans however there were one cluster randomised trial $^{16}$ and two studies with retrospective controls in humans. ${ }^{10,31}$
Seventeen manikin studies were included. All included studies are summarised in Table 1.

Human studies: The mean age of included patients ranged from 62.3 to 68.0 years and the proportion of male subjects ranged from $49.5 \%$ to $75 \%$. No ethnicity data were reported. The OHCA was emergency medical services (EMS) witnessed in 7-11\% cases and received bystander CPR in $42-52 \%$ cases. Mean duration of arrest prior to EMS arrival ranged from 5.5 to $8 \mathrm{~min}$. Rhythm was VF/VT in 26-40\% OHCA cases. All three studies on humans used the Laerdal Q-CPR feedback device or a prototype of the same device.

Manikin studies: Seventeen manikin studies involving HCPs or student HCPs were included. Various feedback devices were investigated; CPREzy (Medteq Innovations Pty Ltd., Brisbane, Australia), ${ }^{18,32-36}$ QCPR (Laerdal Medical, Stavanger, Norway), ${ }^{18,22,37}$ Zoll CPR-plus, ${ }^{38}$ ZOLL Pocket CPR (Zoll Medical Corporation, Chelmsford, USA), ${ }^{19-21}$ voice assist manikin (VAM) (Laerdal Medical, Stavanger, Norway) ${ }^{39-41}$ Heartstart 4000SP(Philips Medical System, Andover, MA, USA)) ${ }^{42}$ and an experimental pressure sensing monitor. ${ }^{43}$ One study compared several types of feedback device to control (no device). ${ }^{18}$ The devices are described in detail in the respective studies.

\subsection{Risk of bias within studies}

Evaluation of bias within the randomised studies is documented in Table 2. Due to the nature of the intervention, all of the included studies had some degree of performance bias as none of the personnel could be blinded. In the studies involving patients, all patients were unconscious at the time of the intervention. None of the studies had blinding of the outcome assessors, so all were at risk 
Table

Summary of characteristics of included studies.

\begin{tabular}{|c|c|c|c|c|c|c|c|}
\hline Study & Country & Sample size & Type & Device & CPR providers & Design & Outcomes \\
\hline Abella $2007^{31}$ & USA & $\begin{array}{l}\text { Intervention } n=101 \\
\text { Control } n=55\end{array}$ & $\begin{array}{l}\text { IHCA } \\
\text { Adult patients } \\
\text { Exclusions - OT/ED IHCA, } \\
\text { subsequent cardiac arrests } \\
\text { in same admission }\end{array}$ & Laerdal QCPR & $\begin{array}{l}\text { Hospital } \\
\text { resuscitation team }\end{array}$ & $\begin{array}{l}\text { Observational } \\
\text { case-control study }\end{array}$ & $\begin{array}{l}\text { Primary - CC rate, CC depth, NFF, ventilation } \\
\text { rate. } \\
\text { Secondary - ROSC, survival to discharge }\end{array}$ \\
\hline Beckers $2007^{32}$ & Germany & $\begin{array}{l}\text { Intervention } n=111 \\
\text { Control } n=91\end{array}$ & $\begin{array}{l}\text { Manikin study } \\
\text { Single rescuer } \\
5 \text { min }\end{array}$ & CPREzy & $\begin{array}{l}\text { Medical students - } \\
\text { nil BLS experience }\end{array}$ & $\begin{array}{l}\text { Randomised } \\
\text { controlled trial }\end{array}$ & $\begin{array}{l}\% \mathrm{CC} \text { rate } 90-110 \mathrm{~min}^{-1}, \% \mathrm{CC} \text { depth } \\
40-50 \mathrm{~mm} \text {, rate of incomplete release of CC, } \\
\text { incorrect hand position }\end{array}$ \\
\hline Boyle $2002^{33}$ & Australia & $n=34$ & $\begin{array}{l}\text { Manikin study } \\
\text { Two rescuers } \\
4 \mathrm{~min}\end{array}$ & CPREzy & $\begin{array}{l}\text { BLS trained } \\
\text { hospital workers } \\
\text { (nurses, physicians } \\
\text { and technicians) }\end{array}$ & $\begin{array}{l}\text { Observational } \\
\text { cross-over trial }\end{array}$ & $\begin{array}{l}\% \text { CC correct position, } \% \text { effective CC, } \\
\text { divergence from CC rate of } 100 \mathrm{~min}^{-1}\end{array}$ \\
\hline Dine $2008^{37}$ & USA & $\begin{array}{l}\text { Intervention } n=31 \\
\text { Control } n=34\end{array}$ & $\begin{array}{l}\text { Manikin study } \\
\text { Single rescuer } \\
2 \mathrm{~min}\end{array}$ & Laerdal QCPR & Nurses & $\begin{array}{l}\text { Randomised } \\
\text { controlled trial }\end{array}$ & $\begin{array}{l}\% \text { CC depth } 38-21 \mathrm{~mm}, \% \text { CC rate } 90-100 \mathrm{~min}^{-1} \text {, } \\
\% \text { correct CC, \% incomplete release, CC } \\
\text { proportion duty cycle, CC rate variability }\end{array}$ \\
\hline Elding $1998^{38}$ & UK & $n=40$ & $\begin{array}{l}\text { Manikin study } \\
\text { Two rescuers } \\
150 \text { CC in } 5: 1 \text { CC to } \\
\text { ventilations ratio }\end{array}$ & CPRPlus & Nurses & $\begin{array}{l}\text { Randomised } \\
\text { cross-over trial }\end{array}$ & $\begin{array}{l}\text { Correct CC per } 150 \text {, incorrect CC pressure } \\
\text { incomplete release, incorrect hand position }\end{array}$ \\
\hline Fischer $2011^{19}$ & USA & $\begin{array}{l}\text { Intervention } n=34 \\
\text { Control } n=34\end{array}$ & $\begin{array}{l}\text { Manikin study } \\
\text { Two rescuers } \\
12 \text { min }\end{array}$ & Zoll Pocket CPR & $\begin{array}{l}\text { BLS trained flight } \\
\text { attendants }\end{array}$ & $\begin{array}{l}\text { Randomised } \\
\text { controlled trial }\end{array}$ & $\begin{array}{l}\text { Mean CC rate, mean CC depth, no-flow time, \% } \\
\text { effective CC, \% correct hand position, } \\
\text { ventilation rate }\end{array}$ \\
\hline Handley $2003^{39}$ & UK & $\begin{array}{l}\text { Intervention } n=18 \\
\text { Control } n=18\end{array}$ & $\begin{array}{l}\text { Manikin study } \\
\text { Single rescuer } \\
3 \text { min }\end{array}$ & VAM & Nurses & $\begin{array}{l}\text { Randomised } \\
\text { controlled trial }\end{array}$ & $\begin{array}{l}\% \text { CC rate } 90-120 \mathrm{~min}^{-1}, \% \mathrm{CC}<38 \mathrm{~mm}, \% \mathrm{CC} \\
>51 \mathrm{~mm}, \% \text { incomplete release, CC proportion } \\
\text { of duty cycle, \% ventilations } 700-1000 \mathrm{ml}\end{array}$ \\
\hline Havel $2010^{23}$ & Austria & $n=24$ & $\begin{array}{l}\text { Manikin study in moving } \\
\text { ambulance/helicopter } \\
\text { Continuous CC } \\
8 \text { min }\end{array}$ & $\begin{array}{l}\text { Philips Modified } \\
\text { Heartstart 4000SP }\end{array}$ & $\begin{array}{l}\text { Pre-hospital health } \\
\text { care providers }\end{array}$ & $\begin{array}{l}\text { Randomised } \\
\text { cross-over trial }\end{array}$ & $\begin{array}{l}\text { \% CC depth } 38-21 \mathrm{~mm}, \% \mathrm{CC} \text { rate } 90-110 \mathrm{~min}^{-1} \text {, } \\
\% \mathrm{CC} \text { correct release, median no-flow time }\end{array}$ \\
\hline Hostler $2005^{40}$ & USA & $n=114$ & $\begin{array}{l}\text { Manikin study } \\
\text { Single rescuer } \\
3 \text { min }\end{array}$ & VAM & $\begin{array}{l}\text { Pre-hospital health } \\
\text { care providers }\end{array}$ & $\begin{array}{l}\text { Randomised } \\
\text { cross-over trial }\end{array}$ & $\begin{array}{l}\text { \% CC correct - rate } 100 \mathrm{~min}^{-1} \text { and depth } \\
38-21 \mathrm{~mm} \text {, mean CC depth. Data collected in } \\
15 \text { second intervals and assessed for decay } \\
\text { over time }\end{array}$ \\
\hline Hostler $2011^{16}$ & USA & $\begin{array}{l}\text { Intervention } n=815 \\
\text { Control } n=771\end{array}$ & $\begin{array}{l}\text { OHCA } \\
\text { Adult patients } \\
\text { Exclusions - trauma, } \\
\text { pregnant, "do not } \\
\text { resuscitate" order }\end{array}$ & Laerdal QCPR & $\begin{array}{l}\text { Pre-hospital health } \\
\text { care providers }\end{array}$ & $\begin{array}{l}\text { Cluster- } \\
\text { randomised } \\
\text { controlled trial }\end{array}$ & $\begin{array}{l}\text { Primary - ROSC } \\
\text { Secondary - survival to discharge, neurological } \\
\text { status (awake) at discharge, CC rate, CC depth, } \\
\text { CC fraction, \% CC with incomplete release, } \\
\text { ventilation rate }\end{array}$ \\
\hline $\begin{array}{l}\text { Kramer-Johansen } \\
2006^{10}\end{array}$ & $\begin{array}{l}\text { Norway, } \\
\text { Sweden and UK }\end{array}$ & $\begin{array}{l}\text { Intervention } n=117 \\
\text { Control } n=241\end{array}$ & $\begin{array}{l}\text { OHCA } \\
\text { Adult patients }\end{array}$ & $\begin{array}{l}\text { Laerdal QCPR } \\
\text { (prototype) }\end{array}$ & $\begin{array}{l}\text { Pre-hospital health } \\
\text { care providers }\end{array}$ & $\begin{array}{l}\text { Observational } \\
\text { case-control study }\end{array}$ & $\begin{array}{l}\text { Primary - CC rate, CC depth, NFF, \% CC } \\
\text { incomplete release, CC proportion of duty } \\
\text { cycle. } \\
\text { Secondary - rate of hospital admission with } \\
\text { ROSC, survival to hospital discharge }\end{array}$ \\
\hline Lyengaraa $2012^{20}$ & Denmark & $\begin{array}{l}\text { Intervention } n=26 \\
\text { Control } n=28\end{array}$ & $\begin{array}{l}\text { Manikin study } \\
\text { Single rescuer } \\
2 \text { min }\end{array}$ & ZOLL AED plus & $\begin{array}{l}\text { CPR conference } \\
\text { attendees }\end{array}$ & $\begin{array}{l}\text { Randomised } \\
\text { controlled trial }\end{array}$ & $\begin{array}{l}\% \mathrm{CC} \text { at target depth }(50-60 \mathrm{~mm}), \% \mathrm{CC} \text { at target } \\
\text { rate }\left(100-120 \mathrm{~min}^{-1}\right)\end{array}$ \\
\hline $\begin{array}{l}\text { Noordergraaf } \\
2006^{34}\end{array}$ & Netherlands & $\begin{array}{l}\text { Intervention } n=112 \\
\text { Control } n=111\end{array}$ & $\begin{array}{l}\text { Manikin study } \\
\text { Two-rescuers } \\
4 \mathrm{~min}\end{array}$ & CPREzy & $\begin{array}{l}\text { BLS trained } \\
\text { hospital workers } \\
\text { (nurses, physicians } \\
\text { and technicians) }\end{array}$ & $\begin{array}{l}\text { Randomised } \\
\text { controlled trial }\end{array}$ & $\begin{array}{l}\text { \% CC ineffective (depth }<40 \mathrm{~mm} \text {, incomplete } \\
\left.\text { release, incorrect duty cycle, rate }<100 \mathrm{~min}^{-1}\right) \text {, } \\
\% \text { leaning, \% incorrect hand position, mean CC } \\
\text { depth }(\mathrm{mm}) \text {, mean CC rate }\left(\mathrm{min}^{-1}\right)\end{array}$ \\
\hline Perkins $2005^{35}$ & UK & $n=20$ & $\begin{array}{l}\text { Manikin study } \\
\text { Continuous CC } \\
3 \text { min }\end{array}$ & CPREzy & $\begin{array}{l}\text { Medical students - } \\
\text { BLS trained }\end{array}$ & $\begin{array}{l}\text { Randomised } \\
\text { cross-over trial }\end{array}$ & $\begin{array}{l}\text { CC rate, depth, duty cycle and correct hand } \\
\text { position }\end{array}$ \\
\hline
\end{tabular}




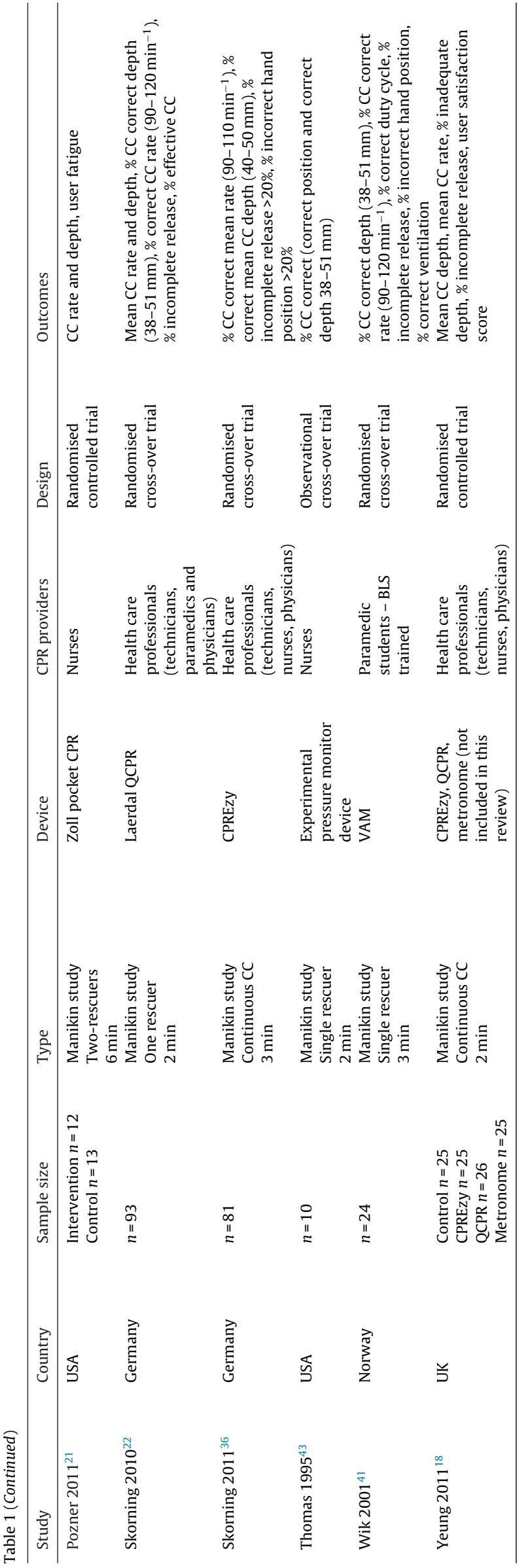

of detection bias. However, as the data items were all objective and many were measured by a computer (for example, CC depth and rate) the bias attributable to lack of blinding was assessed to be minimal. The four non-randomised studies were evaluated for quality and bias using the NOS (Table 3). The two non-randomised studies ${ }^{10,31}$ involving humans rather than manikins used cohorts from sequential time periods. One study ${ }^{10}$ described high attrition rates due to poor data quality. Abella et al. ${ }^{31}$ did not report their attrition rate.

An early study ${ }^{43}$ (1995) enrolled ten participants of undescribed demography who trialled a new feedback device. The device was not capable of providing feedback on CC rate and data on CC rate was not collected in another way. To avoid misleading results of CC depth improvement, this study was not included in meta-analyses.

\subsection{Data analysis issues}

There was a lack of consistency in how data were presented across the studies. Eight studies ${ }^{22,23,32,33,36,37,39,41}$ presented CC data as percentage correct, meaning the proportion of CC that fell within the resuscitation guideline range. These proportions may differ if the same data are analysed for a time period with different guidelines. Six studies $23,32,36,37,39,41$ presented data separately for CC depth and rate. One study ${ }^{33}$ presented data combined as percentage correct $\mathrm{CC}$, meaning at the correct depth and rate. Means and SDs could not be derived from these data, which are reported in Table 4, and therefore they could not be included in the metaanalyses. Skorning ${ }^{22}$ presented mean CC depth and rate as well as percentage $\mathrm{CC}$ in correct range, therefore the data could be included in meta-analyses.

Two studies ${ }^{20,40}$ reported the mean CC rate and depth for several discrete time intervals to investigate deterioration in CPR performance over time. These data were used to calculate an overall mean and SD for the resuscitation period to enable quantitative comparison with other studies.

\subsection{Effects of interventions}

1. Patient outcomes: Only one study ${ }^{16}$ (a cluster RCT) reported on the primary outcome of this review. There was no difference in neurologically intact survival to hospital discharge between the groups with and without real-time CPR feedback using a definition of being discharged awake. Three studies (one cluster RCT ${ }^{16}$ and two observational case control studies ${ }^{10,31}$ ) reported on ROSC (Fig. 2.1) and survival to hospital discharge (Fig. 2.2). All reported no significant difference.

Hostler et al. ${ }^{16}$ performed a retrospective analysis which showed that survival and ROSC were related to time period and that early clusters were likely to do better with "feedback off" (cluster adjusted mean difference in \% survival 5.5, 95\% CI 9.6-1.3 lower in early clusters). However the difference was not significant for later clusters. The authors suggested this could be due to a learning curve when using the device.

2. CPR quality: Data are represented in Fig. 3. Three studies using human subjects, ${ }^{10,16,31}$ and nine manikin studies ${ }^{18-22,34,35,39,40}$ that presented data on CC quality were used in the meta-analyses. All three human studies ${ }^{10,16,31}$ presented data on CC depth, rate and NFF. Eight manikin studies compared CC depth, ${ }^{18-22,34,35,40}$ seven compared CC rate, ${ }^{18-22,34,39}$ and one reported data on NFF. ${ }^{19}$ Six studies $^{23,32,36,37,39,41}$ presented data as percentage of CC that fell within the correct range for depth and/or rate. These data are presented separately.

2.1 Human studies: Meta-analysis of CPR data quality revealed mean CC depth increased by more than $2.5 \mathrm{~mm}$ (95\% CI 0.9-4.3) 
Table 2

Risk of bias in included randomised controlled trials.

\begin{tabular}{|c|c|c|c|c|}
\hline & \multicolumn{2}{|l|}{ Selection bias } & \multirow[t]{2}{*}{ Attrition bias } & \multirow[t]{2}{*}{ Reporting bias } \\
\hline & Randomisation & Allocation concealment & & \\
\hline Hostler 2011 & $\begin{array}{l}\text { Low risk - cluster randomised } \\
\text { trial }\end{array}$ & $\begin{array}{l}\text { Low risk - randomised } \\
\text { externally to conceal }\end{array}$ & $\begin{array}{l}\text { High risk. CPR data unavailable } \\
\text { in } 26 \% \text {. Potentially biases due } \\
\text { to differences in arrest data } \\
\text { from group without CPR data }\end{array}$ & $\begin{array}{l}\text { Low risk - report positive and } \\
\text { neutral outcomes }\end{array}$ \\
\hline Dine 2008 & Low risk - randomised & Unclear risk - not stated & $\begin{array}{l}\text { Missing data for } 19 \% \\
\text { participants. Not included in } \\
\text { analysis. Not reported which } \\
\text { group. }\end{array}$ & $\begin{array}{l}\text { Low risk } \\
\text { Report positive and neutral } \\
\text { outcomes }\end{array}$ \\
\hline Skorning 2010 & $\begin{array}{l}\text { Low risk - randomly assigned } \\
\text { to intervention or control first }\end{array}$ & Unclear risk - not stated & Unclear - not reported & Unclear - not reported \\
\hline Yeung 2011 & $\begin{array}{l}\text { Low risk - randomised to } \\
\text { control or intervention }\end{array}$ & Unclear risk - not stated & Low risk - attrition rate $2 \%$ & $\begin{array}{l}\text { Low risk - report negative and } \\
\text { positive findings }\end{array}$ \\
\hline Beckers 2007 & Low risk - randomised & Unclear risk - not stated & $\begin{array}{l}\text { Unclear risk - excluded an } \\
\text { undisclosed number of } \\
\text { participants who failed to } \\
\text { attend for the second test } \\
\text { resulting in unequal group size. }\end{array}$ & $\begin{array}{l}\text { Low risk - report positive and } \\
\text { negative findings }\end{array}$ \\
\hline Noordergraaf 2006 & Low risk - randomised & Unclear - not stated & $\begin{array}{l}\text { Low risk - no missing data. } \\
\text { Included data even if full task } \\
\text { not completed (3\%) }\end{array}$ & $\begin{array}{l}\text { Low risk - report positive } \\
\text { neutral data }\end{array}$ \\
\hline Perkins 2005 & Low risk - randomised & Unclear risk - not stated & $\begin{array}{l}\text { Unclear risk. Nil missing data } \\
\text { but } 3 / 20 \text { participants replaced } \\
\text { with height/age/sex matched } \\
\text { participants for second stage }\end{array}$ & $\begin{array}{l}\text { Low risk - report positive and } \\
\text { neutral data }\end{array}$ \\
\hline Skorning 2011 & Low risk - randomised & Unclear risk - not stated & Unclear risk - not reported & Not reported \\
\hline Elding 1998 & $\begin{array}{l}\text { Low risk - randomised cross } \\
\text { over }\end{array}$ & Unclear risk - not stated & Unclear risk - not reported & Low risk - all data reported \\
\hline Fischer 2011 & Low risk - randomised & $\begin{array}{l}\text { Unclear risk -allocation } \\
\text { generated by 3rd party }\end{array}$ & $\begin{array}{l}\text { Low risk - attrition rate } 3 \% \\
\text { intervention, } 6 \% \text { control group }\end{array}$ & $\begin{array}{l}\text { Low risk - report positive and } \\
\text { negative outcomes }\end{array}$ \\
\hline Lyengaraa 2012 & Low risk - randomised & $\begin{array}{l}\text { Low risk. Concealed in } \\
\text { envelope. }\end{array}$ & $\begin{array}{l}\text { Unclear risk. Data missing from } \\
\text { feedback group } 13 \% \text { and } \\
\text { non-feedback group } 7 \% \text {. }\end{array}$ & $\begin{array}{l}\text { Low risk. } \\
\text { No positive outcomes reported }\end{array}$ \\
\hline Pozner 2011 & Low risk - randomised & Unclear - not stated & Unclear risk - not reported & Unclear risk - not reported \\
\hline Handley 2003 & Low risk - randomised & Low risk - concealed & Low risk - no missing data & $\begin{array}{l}\text { Low risk - report positive and } \\
\text { negative data }\end{array}$ \\
\hline Hostler 2005 & Low risk - randomised & Unclear risk - not stated & Unclear risk - not reported & $\begin{array}{l}\text { Low risk - report both positive } \\
\text { and negative data }\end{array}$ \\
\hline Wik 2001 & Low risk randomised cross over & Low risk - concealed & Unclear risk - not reported & $\begin{array}{l}\text { Low risk - report positive and } \\
\text { negative findings }\end{array}$ \\
\hline Havel 2010 & $\begin{array}{l}\text { Low risk - randomised } \\
\text { cross-over }\end{array}$ & Low risk - concealed until start & Unclear risk - not reported & $\begin{array}{l}\text { Low risk - report positive and } \\
\text { neutral findings }\end{array}$ \\
\hline
\end{tabular}

(Fig. 3.1), mean CC rate decreased by more than 6 per minute (95\% CI 2.4-10.7) (Fig. 3.2) and NFF decreased by $1.9 \%$ (95\% CI 1.8-2.0)

(Fig. 3.3) when participants used the feedback devices.

2.2 Manikin studies: Analysis of the CC depth data from manikin studies revealed significant heterogeneity precluding meta-analysis $\left(I^{2}=87 \%\right)$. When the manikin studies were analysed by device type, a significant increase in CC depth was only seen with the CPREzy device $(6.2 \mathrm{~mm}, 95 \% \mathrm{CI} 3.88-8.48)$. For all other devices studies were too heterogeneous to combine even in sub-groups (Fig. 3.1).

Table 3

Quality assessment of included non-randomised trials using Newcastle Ottawa Scale ${ }^{27}$.

\begin{tabular}{|c|c|c|c|}
\hline Study & $\begin{array}{l}\text { Selection of study group } \\
\text { Maximum } 4 \text { stars }\end{array}$ & $\begin{array}{l}\text { Comparability of study group } \\
\text { Maximum } 2 \text { stars }\end{array}$ & $\begin{array}{l}\text { Assessment of outcome } \\
\text { Maximum } 3 \text { stars }\end{array}$ \\
\hline Abella 2007 & $\begin{array}{l}\star \star \star \star \\
\text { Represented target population well. } \\
\text { Control and intervention groups from } \\
\text { same hospital. }\end{array}$ & $\begin{array}{l}\star \\
\text { Cohorts collected over consecutive time } \\
\text { periods. No significant difference in } \\
\text { demographics/arrest details between two } \\
\text { groups. }\end{array}$ & $\begin{array}{l}\star \star \\
\text { Outcome assessment not blind but } \\
\text { objective. Follow-up until discharge. Lost } \\
\text { to follow-up data not presented. }\end{array}$ \\
\hline Kramer-Johansen 2006 & $\begin{array}{l}\star \star \star \star \\
\text { Represented target population well. } \\
\text { Control and intervention groups from } \\
\text { same centres. }\end{array}$ & $\begin{array}{l}\star \\
\text { Cohorts collected over consecutive time } \\
\text { periods. No significant difference in } \\
\text { demographics/arrest details between two } \\
\text { groups. }\end{array}$ & $\begin{array}{l}\star \\
\text { Outcome assessment not blind but } \\
\text { objective. Follow-up until discharge. } 27 \% \text { of } \\
\text { control and } 8 \% \text { of intervention group not } \\
\text { included due to poor data quality. }\end{array}$ \\
\hline Boyle 2002 & $\begin{array}{l}\star \star \star \star \\
\text { Participants represented the population of } \\
\text { hospital workers who would perform CPR } \\
\text { well. }\end{array}$ & $\begin{array}{l}\star \star \\
\text { Same participants for both control and } \\
\text { intervention ( } 24 \mathrm{~h} \text { rest between). }\end{array}$ & $\begin{array}{l}\star \star \\
\text { Assessment of outcome was not blind but } \\
\text { was objective. Follow up was long enough } \\
\text { ( } 4 \text { min). The study does not report an } \\
\text { attrition rate. }\end{array}$ \\
\hline Thomas 1995 & $\begin{array}{l}\star \star \\
\text { Only ten participants limiting } \\
\text { generalisability. }\end{array}$ & $\begin{array}{l}\star \\
\text { Same participants for both control and } \\
\text { intervention (no record of rest period). }\end{array}$ & $\begin{array}{l}\star \\
\text { Assessment of outcome was not blind but } \\
\text { was objective. Do not record CC rate. }\end{array}$ \\
\hline
\end{tabular}


Table 4

Effect of intervention on CPR quality. For studies presenting data as percentage within correct range.

\begin{tabular}{|c|c|c|c|c|}
\hline \multirow[t]{2}{*}{ Device type and study } & \multicolumn{2}{|c|}{$\%$ CC correct depth range } & \multicolumn{2}{|c|}{$\%$ CC correct rate range } \\
\hline & Control & Feedback & Control & Feedback \\
\hline $\begin{array}{l}\text { 1.5 Dine } 2008^{37} \\
\text { QCPR }\end{array}$ & $19 \%$ & $58 \% p=0.002$ & $45 \%$ & $45 \% p=1.0$ \\
\hline $\begin{array}{l}2.1 \text { Beckers } 2007^{32} \\
\text { CPREzy }\end{array}$ & $19.8 \%$ & $93.7 \% p<0.001$ & $34.1 \%$ & $71.2 \% p<0.01$ \\
\hline $\begin{array}{l}\text { 2.5 Skorning } 2011^{36} \\
\text { CPREzy }\end{array}$ & $51.2 \%$ & $87.8 \% p<0.001$ & $12.2 \%$ & $82.9 \% p<0.001$ \\
\hline $\begin{array}{l}5.1 \text { Handley } 2003^{39} \\
\text { VAM }\end{array}$ & $11.4 \%$ & $56.0 \% p<0.001$ & & \\
\hline $\begin{array}{l}5.4 \text { Wik } 2001^{41} \\
\text { VAM }\end{array}$ & $32 \%$ & $92 \% p=0.002$ & & \\
\hline $\begin{array}{l}6.1 \text { Havel } 2010^{23} \\
\text { Heartstart } 4000 S P\end{array}$ & $93 \%$ & $97 \% p=0.03$ & $44 \%$ & $90 \% p<0.001$ \\
\hline
\end{tabular}

A decrease in CC rate of almost 10 per minute (95\% CI 5.4-13.9) was seen when participants used feedback devices when data from all manikin studies were combined (Fig. 3.2.2). When sub-grouped by device type (Fig. 3.2) significant heterogeneity precluded metaanalysis for all aside from the Laerdal QCPR device which showed a decrease in CC rate of 7 per minute (95\% CI 3.28-10.96) when using the feedback device.

The only manikin study that reported $\mathrm{NFF}^{19}$ found a nonsignificant decrease with the use of the feedback device.

Data from the six studies $23,32,36,37,39,41$ that reported percent of CC within correct depth range or correct rate range are presented in Table 4. All six studies reported a significant increase in the proportion of CC within the correct depth range when using a feedback device. Four of the studies $23,32,36,37$ reported on CC rate; three of these $\mathrm{e}^{24,30,35}$ reported a significant increase in the proportion of CC within the correct rate range when using feedback devices. A further two studies ${ }^{38,43}$ only presented data on correct CC pressure and did not state how this correlated to CC depth and so could not be included in the meta-analyses. Both studies stated that the mean proportion of correct CC significantly increased $(p<0.05)$ when participants used the feedback device.

CPR quality data presented by the included studies but not included in this systematic review are documented in Table 1.
3. Adverse events and HCP satisfaction data: Occurrence of adverse events was not consistently reported. Of the three studies involving human patients, only one ${ }^{16}$ mentioned adverse patient events, stating that there were none reported, and none reported data on user satisfaction.

Eight manikin studies ${ }^{18,21,22,32,35-38}$ reported user satisfaction and/or adverse event data. There were no reports of major adverse events to the HCP. One study ${ }^{35}$ reported a minor soft tissue injury to the BLS provider resulting from the hand being caught between the device and the manikin during compressions. The reported rate of user satisfaction was highly variable between studies. The CPREzy was reported to be uncomfortable to use by $16 \%{ }^{36}$ of HCPs in one study and $95 \%$ in another. ${ }^{35}$ Similarly opinions about usefulness of the CPREzy device varied between $48 \%{ }^{35}$ and $75.5 \%{ }^{32}$ The QCPR device was rated as "helpful" by $85 \%$ and $87 \%$ of participants in two studies. ${ }^{22,37}$ One study ${ }^{18}$ compared user satisfaction between control, QCPR and CPREzy and found users scored QCPR higher in terms of comfort, ease of use, distraction and confidence in the device. Another study 38 reporting on user satisfaction of CPRPlus found 25\% complained of at least one of the following: increased effort to perform CPR, user pain and/or the device's slippery surface. One study ${ }^{21}$ found $85 \%$ of participants reported the ZOLL Pocket CPR device was

\begin{tabular}{|c|c|c|c|c|c|c|c|c|}
\hline $\begin{array}{l}2.1 \\
\text { Study or Subgroup }\end{array}$ & $\begin{array}{l}\text { Feedba } \\
\text { Events }\end{array}$ & $\begin{array}{l}\text { ON } \\
\text { Total }\end{array}$ & $\begin{array}{l}\text { Contr } \\
\text { Events }\end{array}$ & $\begin{array}{l}\text { ol } \\
\text { Total }\end{array}$ & Weight & $\begin{array}{c}\text { Odds Ratio } \\
\text { M-H, Random, } 95 \% \mathrm{Cl}\end{array}$ & $\begin{array}{c}\text { Odds Ratio } \\
\text { M-H, Random, } 95 \% \mathrm{Cl}\end{array}$ & \\
\hline Abella 2007 & 45 & 101 & 22 & 55 & $7.2 \%$ & $1.21[0.62,2.35]$ & & \\
\hline Hostler 2011 & 361 & 815 & 345 & 771 & $81.9 \%$ & $0.98[0.81,1.20]$ & & \\
\hline Kramer-Johansen 2006 & 27 & 117 & 42 & 241 & $10.9 \%$ & $1.42[0.83,2.45]$ & & \\
\hline Total $(95 \% \mathrm{Cl})$ & & 1033 & & 1067 & $100.0 \%$ & $1.04[0.87,1.24]$ & & \\
\hline Total events & 433 & & 409 & & & & & \\
\hline $\begin{array}{l}\text { Heterogeneity: } \mathrm{Tau}^{2}=0 \text {. } \\
\text { Test for overall effect: } 7\end{array}$ & $\begin{array}{l}\text { Chi }{ }^{2}=1 \\
0.40(P=\end{array}$ & 78, df = & $2(P=0$. & 41); $1^{2}$ & $0 \%$ & & $0.2 \quad 0.5$ & 5 \\
\hline
\end{tabular}

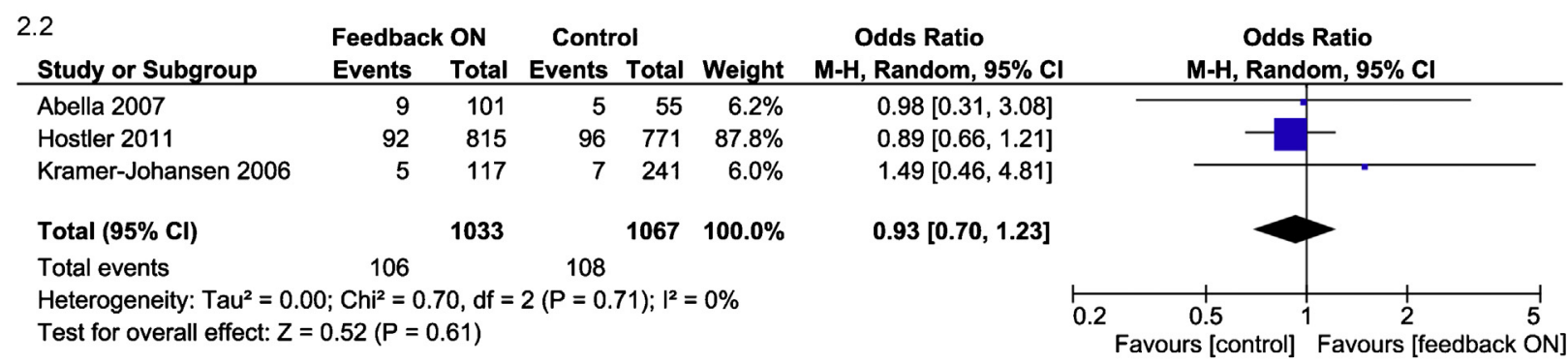

Fig. 2. Patient outcomes - comparison of feedback vs. control. (2.1) ROSC. (2.2) Survival to hospital discharge. 

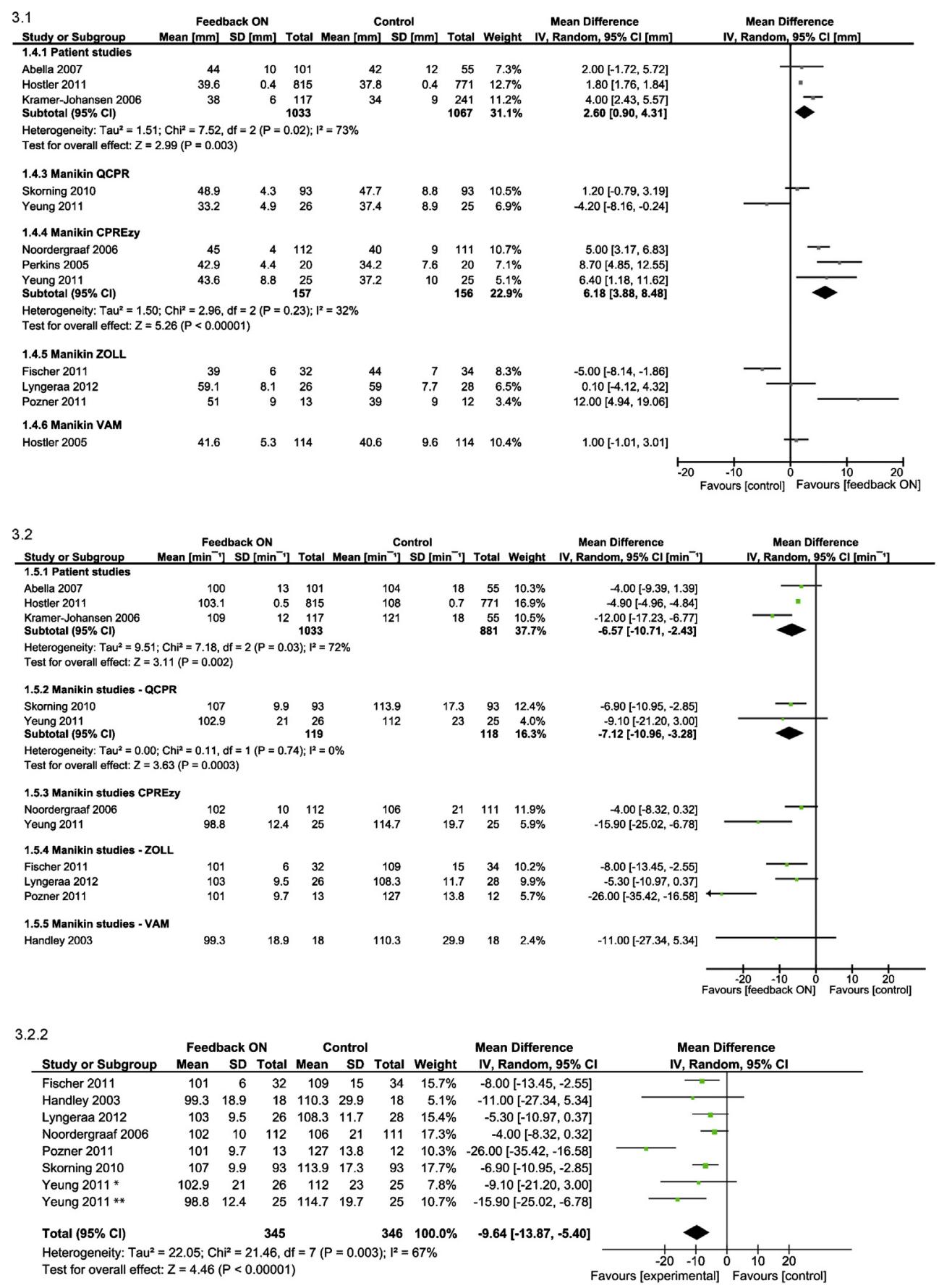

Yeung 2011* CPREzy Yeung $2011^{* *}$ QCPR

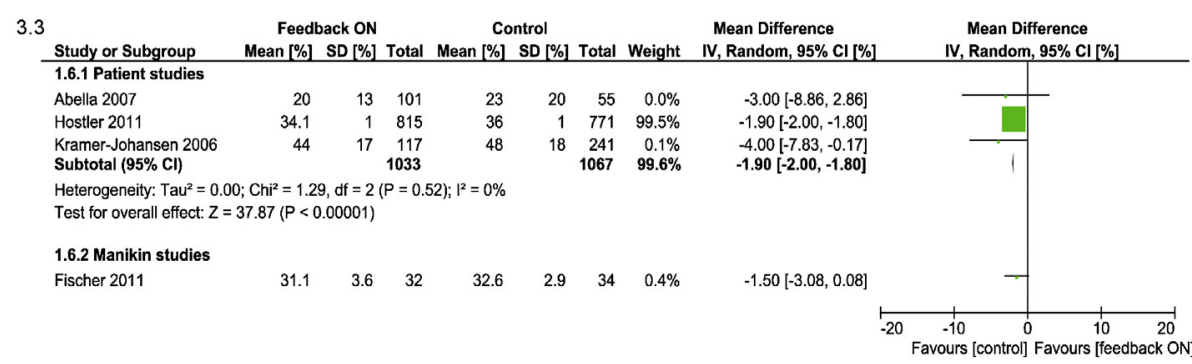

Fig. 3. CPR quality - comparison of feedback vs. control. (3.1) Chest compression depth [mm]. Patient and manikin studies - sub-grouped by device type. All patient studies used QCPR device. (3.2) Chest compression rate [ $\mathrm{min}^{-1}$ ]. Patient and manikin studies - sub-grouped by device type. All patient studies used QCPR device. (3.2.2) Chest compression rate [min ${ }^{-1}$ ]. Manikin studies only, no sub-grouping. (3.3) No-flow fraction [\%]. Patient and manikin studies - sub-grouped by device type. All patient studies used QCPR device. 
helpful and none reported that it increased user perception of fatigue.

\subsection{Subgroup analysis}

Human studies have been discussed separately from manikin studies. Manikin studies have been sub-analysed by device type used. There was only one study involving IHCA in patients ${ }^{31}$ and removing it from the analysis did not change the outcomes of metaanalyses of patient studies.

\subsection{Risk of bias across studies}

Evidence of heterogeneity varied depending on outcome assessed. For patient outcomes in the human studies heterogeneity was low $\left(I^{2}=0 \%\right)$. For the outcome of CC rate and depth there was significant evidence of heterogeneity with $I^{2}$ values of $72 \%$ and $73 \%$ respectively. For the outcome measure of NFF, $I^{2}$ was $0 \%$ suggesting homogeneity.

Heterogeneity amongst manikin studies was also high with $I^{2}$ of $67 \%$ and $87 \%$ respectively for CC rate and depth. This remained following subgroup analysis, ranging from 0 to $86 \%$ for CC rate and 32 to $90 \%$ for CC depth. Meta-analysis was not performed for subgroups with $I^{2}>75 \%$.

To explore heterogeneity attributable to publication bias, funnel plots were drawn, but no marked asymmetry was observed (Appendix 3).

\section{Discussion}

Overall, the evidence is not sufficiently robust to determine the effectiveness of feedback devices in improving outcomes following cardiac arrest. Only three studies (one cluster randomised, two nonrandomised) with a total of 2100 human subjects were identified following an extensive search of the literature. The studies were clinically heterogeneous, of variable quality and reported on different outcome variables. The only available data on neurologically intact survival came from one study, ${ }^{16}$ which reported no significant change when real time feedback was used. This ${ }^{16}$ showed some evidence of improved survival to hospital discharge when only the later stages of the study were analysed, it was not statistically significant. Nor was there any evidence of a change in survival outcome or ROSC from any of the human studies.

Both manikin and human studies provided evidence that realtime feedback enables a wide range of HCPs to follow life support guidelines more closely within a broad range of settings. Although there was not uniform improvement in CPR variables throughout all studies, there is a significant body of evidence to suggest that audiovisual feedback devices can guide a rescuer to provide deeper $\mathrm{CC}$, at a rate closer to that recommended, and reduce NFF when used in real time whilst delivering CPR. This is consistent with the conclusion from the previous systematic review by Yeung et al., $^{13}$ that there was good evidence supporting the use of feedback devices during training to provide skill acquisition and retention.

A variety of reasons explain why the improvement in CPR variables was not translated into improved patient outcomes. Firstly, effective CPR is just one of many links in the chain of survival and all links need to be in place to allow survival. Without early CPR and bystander delivery of CPR the effect of improving the quality of CPR once trained rescuers arrive may be diminished. Secondly, the improvement in CC variables may be too small to make a noticeable difference to survival especially if the improvements are inconsistent. Additional support may be necessary to increase the magnitude of these improvements, such as staff training and familiarization with the devices, as was seen in the Hostler study, ${ }^{16}$ which only compared the later stages of use to control the outcomes that trended towards improvement. Other adjuncts may include post-event feedback sessions that have been shown to increase the extent of improvement in some centres. ${ }^{37,44}$

Many of these studies were based on the 2000 ILCOR resuscitation guidelines which place less emphasis on reducing interruptions to CC and maintaining a CC rate of at least 100 per minute than the 2010 version. Device feedback resulted in reducing the mean $\mathrm{CC}$ rate, which may not be advantageous. The optimal rate of chest compression in CPR remains unknown. Current advice to compress at a rate of 100/minute or greater comes from large mammal studies in which a rate of $100 /$ min was compared with $80 / \mathrm{min}$ and showed significantly better coronary perfusion, cardiac output and survival. ${ }^{45}$ Clinical studies in adults have also shown end-tidal carbon dioxide levels, a surrogate marker of cardiac output during CPR, to be higher with a chest compression rate of $120 /$ min when compared with $80 / \mathrm{min}^{46}$ Another recent study found an increase in odds of ROSC with increasing CC rates up to $125 / \mathrm{min} ;{ }^{47}$ this was not associated with a similar change in survival to discharge.

Few recent studies evaluate the use of feedback devices with 2010 ILCOR guidelines. There is one such multicenter study underway, comparing the use of the QCPR device with and without post debriefing feedback with an estimated recruitment of over 900 patients in the UK. ${ }^{48}$ There is an understandable lack of evidence of patient outcomes dependent on what CC rate and depth the feedback device is set to prompt the provider to. Although this could be incredibly useful and interesting data it would be ethically difficult.

\section{Limitations}

As described above, our systematic review was challenged by significant statistical and clinical heterogeneity among the studies. Various feedback devices were used, different CPR guidelines were applied, HCPs differed in clinical experience, and different outcomes reported. Study quality varied and it is questionable whether evidence provided by manikin studies can be applied to cardiac arrest in humans.

One particular limitation of including a variety of feedback devices is that they differ in the way that feedback is delivered. For example CPREzy gives guidance feedback whereas QCPR gives corrective feedback and this may result in different responses from the user. This varied response of the user depending on type of feedback provided may explain some of the difference in performance of the various devices (Figs. 3.1 and 3.2). Caution should be used when interpreting data with various device types grouped together (Fig. 3.2.2).

Other devices are available to aid CPR providers in performing high quality CPR such as mobile applications, ${ }^{49}$ motion sensing devices $^{50}$ and metronomes ${ }^{51}$ and some have been used by nonHCPs to aid CPR provision in lay providers. ${ }^{49,50}$ These devices were determined to be out of the scope of this systematic review, but would provide an interesting area for future research.

\section{Authors conclusion}

There is a significant body of evidence to suggest that the use of real-time feedback devices during a resuscitation attempt can result in rescuers providing CC parameters close to recommendations. The anticipated result of an improvement in patient outcome has not been observed, although there has been no deterioration in outcome either. Real-time feedback may be useful in both teaching scenarios and clinical settings to increase awareness of CPR technique and improve CC quality.

Further research is warranted into the ability of these devices to improve patient outcomes given that the new resuscitation guidelines include a faster target CC rate and more emphasis on 
reducing interruptions to $\mathrm{CC}$. Further research is also awaited on the ability of combining real-time feedback and post-event debriefing to improve outcomes. This must be done in conjunction with optimisation of all other elements of the chain of survival including improving rates of bystander CPR and timely access to post-resuscitation care.

\section{Conflict of interest statement}

Judith Finn receives partial salary support from St John Ambulance (Western Australia); has received travel reimbursement from the American Heart Association for attendance at ILCOR meetings; and travel reimbursement from the Australian Resuscitation Council for teaching on Advanced Life Support Instructor courses.

Judith Finn is the Director of the Australian Resuscitation Outcomes Consortium and Co-Chair of the ILCOR Education, Implementation and Teams Taskforce.

Ian Jacobs is the Clinical Services Director at St John Ambulance Western Australia has received travel reimbursement from the Australian Resuscitation Council for attendance at ILCOR meetings for teaching on Advanced Life Support courses. Ian Jacobs is Western Australian and National Chair of the Australian Resuscitation Council and Co-Chair of ILCOR.

\section{Appendix A. Supplementary data}

Supplementary data associated with this article can be found, in the online version, at http://dx.doi.org/10.1016/j.resuscitation. 2013.12.012.

\section{References}

1. Kong MH, Fonarow GC, Peterson ED et al. Systematic review of the incidence of sudden cardiac death in the United States. J Am Coll Cardiol 2011;57:794-801.

2. Berdowski J, Berg RA, Tijssen JGP, Koster RW. Global incidences of out-ofhospital cardiac arrest and survival rates: systematic review of 67 prospective studies. Resuscitation 2010;81:1479-87.

3. Nichol G, Thomas E, Callaway CW, et al. Regional variation in out-of-hospital cardiac arrest incidence and outcome. JAMA: J Am Med Assoc 2008;300:1423-31.

4. Nolan JP, Hazinski MF, Billi JE, et al. Part 1: Executive summary: 2010 International Consensus on Cardiopulmonary Resuscitation and Emergency Cardiovascular Care Science With Treatment Recommendations. Resuscitation 2010;81:e1-25.

5. Cummins RO, Ornato JP, Thies WH, Pepe PE. Improving survival from sudden cardiac arrest: the "chain of survival" concept. A statement for health professionals from the Advanced Cardiac Life Support Subcommittee and the Emergency Cardiac Care Committee, American Heart Association. Circulation $1991 ; 83: 1832-47$

6. Sayre MR, Koster RW, Botha M, et al. Part 5: Adult Basic Life Support. Circulation 2010;122:S298-324

7. Berg RA, Sanders AB, Kern KB, et al. Adverse hemodynamic effects of interrupting chest compressions for rescue breathing during cardiopulmonary resuscitation for ventricular fibrillation cardiac arrest. Circulation 2001;104:2465-70.

8. Kern KB, Hilwig RW, Berg RA, Sanders AB, Ewy GA. Importance of continuous chest compressions during cardiopulmonary resuscitation. Circulation 2002;105:645-9.

9. Eftestøl T, Sunde K, Steen PA. Effects of interrupting precordial compressions on the calculated probability of defibrillation success during out-of-hospital cardiac arrest. Circulation 2002;105:2270-3.

10. Kramer-Johansen J, Myklebust H, Wik L, et al. Quality of out-of-hospital cardiopulmonary resuscitation with real time automated feedback: a prospective interventional study. Resuscitation 2006;71:283-92.

11. Christenson J, Andrusiek D, Everson-Stewart S, et al. Chest compression fraction determines survival in patients with out-of-hospital ventricular fibrillation. Circulation 2009;120:1241-7.

12. Wik L, Kramer-Johansen J, Myklebust H, et al. Quality of cardiopulmonary resuscitation during out-of-hospital cardiac arrest. JAMA 2005;293:299-304

13. Yeung J, Meeks R, Edelson D, Gao F, Soar J, Perkins GD. The use of CPR feedback/prompt devices during training and CPR performance: a systematic review. Resuscitation 2009;80:743-51

14. Bohn A, Weber TP, Wecker S, et al. The addition of voice prompts to audiovisual feedback and debriefing does not modify CPR quality or outcomes in out of hospital cardiac arrest-a prospective, randomized trial. Resuscitation 2011;82:257-62.
15. Olasveengen TM, Tomlinson AE, Wik L, et al. A failed attempt to improve quality of out-of-hospital CPR through performance evaluation. Prehosp Emerg Care 2007;11:427-33 [Date of Publication: October 2007].

16. Hostler D, Everson-Stewart S, Rea TD, et al. Effect of real-time feedback during cardiopulmonary resuscitation outside hospital: prospective, clusterrandomised trial. BMJ 2011:2011.

17. Chandra S, Hess EP, Kolb L, Myers L, White RD. Effect of real-time automated and delayed summative feedback on CPR quality in adult out-of-hospital cardiac arrest: a prospective multicenter controlled clinical trial. Acad Emerg Med 2011;15:S6-145.

18. Yeung J, Perkins G. A randomised controlled trial of prompt and feedback devices and its impact on quality of chest compressions in Immediate Life Support (ILS) training. Resuscitation 2011;82:S11.

19. Fischer H, Gruber J, Neuhold S, et al. Effects and limitations of an AED with audiovisual feedback for cardiopulmonary resuscitation: a randomized manikin study. Resuscitation 2011;82:902-7.

20. Lyngeraa TS, Hjortrup PB, Wulff NB, Aagaard T, Lippert A. Effect of feedback on delaying deterioration in quality of compressions during 2 minutes of continuous chest compressions: a randomized manikin study investigating performance with and without feedback. Scand J Trauma Resusc Emerg Med 2012;20:16.

21. Pozner CN, Almozlino A, Elmer J, Poole S, McNamara D, Barash D Cardiopulmonary resuscitation feedback improves the quality of chest compression provided by hospital health care professionals. Am J Emerg Med 2011:29:618-25.

22. Skorning M, Beckers SK, Brokmann JC, et al. New visual feedback device improves performance of chest compressions by professionals in simulated cardiac arrest. Resuscitation 2010;81:53-8.

23. Havel C, Schreiber W, Trimmel H, et al. Quality of closed chest compression on a manikin in ambulance vehicles and flying helicopters with a real time automated feedback. Resuscitation 2010;81:59-64.

24. Kirkbright S, Finn J, Jacobs I, Sprivulis P, Thompson P. The relationship between quality of cardiopulmonary resuscitation performed by healthcare professionals and patient survival following cardiac arrest: a systematic review of randomised and non-randomised trials. PROSPERO: International Prospective Register of Systematic Reviews; 2013. CRD42012003064.

25. Vandenbroucke JP, Von Elm E, Altman DG, et al. Strengthening the reporting of observational studies in epidemiology (STROBE): explanation and elaboration. Gac Sanit 2009;23:26.

26. Higgins JPT, Green S. Cochrane Handbook for Systematic Reviews of Interventions Version 5.1.0 [updated March 2011]. The Cochrane Collaboration: 2011.

27. Wells GA, Shea B, O'Connell D, et al. The Newcastle-Ottawa Scale (NOS) for assessing the quality of nonrandomized studies in meta-analyses; 2009. Available from: http://wwwohrica/programs/clinical_epidemiology/oxfordhtm [cited 2009 October 19].

28. The Nordic Cochrane Centre TCC. Review Manager (RevMan) [Computer program]. Version 5.2. Copenhagen; 2012.

29. Liberati A, Altman DG, Tetzlaff J, et al. The PRISMA statement for reporting systematic reviews and meta-analyses of studies that evaluate health care interventions: explanation and elaboration. PLoS Med 2009;6:e1000100.

30. Higgins JP, Thompson SG, Deeks JJ, Altman DG. Measuring inconsistency in metaanalyses. BMJ 2003;327:557-60.

31. Abella BS, Edelson DP, Kim S, et al. CPR quality improvement during in-hospita cardiac arrest using a real-time audiovisual feedback system. Resuscitation 2007;73:54-61.

32. Beckers SK, Skorning MH, Fries M, et al. CPREzy improves performance of external chest compressions in simulated cardiac arrest. Resuscitation 2007;72:100-7

33. Boyle AJ, Wilson AM, Connelly K, McGuigan L, Wilson J, Whitbourn R. Improvement in timing and effectiveness of external cardiac compressions with a new non-invasive device: the CPR-Ezy. Resuscitation 2002;54:63-7.

34. Noordergraaf GJ, Drinkwaard BWPM, van Berkom PFJ, et al. The quality of chest compressions by trained personnel: the effect of feedback, via the CPREzy, in a randomized controlled trial using a manikin model. Resuscitation 2006;69:241-52.

35. Perkins GD, Augré C, Rogers H, Allan M, Thickett DR. CPREzy ${ }^{\mathrm{TM}}$ : an evaluation during simulated cardiac arrest on a hospital bed. Resuscitation 2005;64: 103-8.

36. Skorning M, Derwall M, Brokmann JC, et al. External chest compressions using a mechanical feedback device: cross-over simulation study. Anaesthesist 2011;60:717-22.

37. Dine CJ, Gersh RE, Leary M, Riegel BJ, Bellini LM, Abella BS. Improving cardiopulmonary resuscitation quality and resuscitation training by combining audiovisual feedback and debriefing. Crit Care Med 2008;36:2817-22.

38. Elding C, Baskett P, Hughes A. The study of the effectiveness of chest compres sions using the CPR-plus. Resuscitation 1998;36:169-73.

39. Handley AJ, Handley SA. Improving CPR performance using an audible feedback system suitable for incorporation into an automated external defibrillator. Resuscitation 2003;57:57-62.

40. Hostler D, Wang H, Parrish K, Platt TE, Guimond G. The effect of a voice assist manikin (VAM) system on CPR quality among prehospital providers. Prehosp Emerg Care 2005;9:53-60.

41. Wik L, Thowsen J, Andreas Steen P. An automated voice advisory manikin system for training in basic life support without an instructor. A novel approach to CPR training. Resuscitation 2001;50:167-72. 
42. Havel C, van Tulder R, Schreiber W, et al. Randomized crossover trial comparing physical strain on advanced life support providers during transportation using real-time automated feedback. Acad Emerg Med 2011;18:860-7.

43. Thomas SH, Stone CK, Austin PE, March JA, Brinkley S. Utilization of a pressuresensing monitor to improve in-flight chest compressions. Am J Emerg Med 1995;13:155-7.

44. Edelson DP, Litzinger B, Arora V, et al. Improving in-hospital cardiac arrest process and outcomes with performance debriefing. Arch Intern Med 2008; 168:1063-9

45. Maier GW, Tyson GS, Olsen CO, et al. The physiology of external cardiac massage: high-impulse cardiopulmonary resuscitation. Circulation 1984;70:86-101.

46. Kern KB, Sanders AB, Raife J, Milander MM, Otto CW, Ewy GA. A study of chest compression rates during cardiopulmonary resuscitation in humans: the importance of rate-directed chest compressions. Arch Intern Med 1992;152:145-9.
47. Idris AH, Guffey D, Aufderheide TP, et al. Relationship between chest compression rates and outcomes from cardiac arrest. Circulation 2012;125: 3004-12.

48. Perkins GD, Davies RP, Quinton S, et al. The effect of real-time CPR feedback and post event debriefing on patient and processes focused outcomes: a cohort study: trial protocol. Scand J Trauma Resusc Emerg Med 2011;19:58.

49. Zanner R, Wilhelm D, Feussner H, Schneider G. Evaluation of M-AID ${ }^{\circledR}$, a first aid application for mobile phones. Resuscitation 2007;74:487-94.

50. Semeraro F, Frisoli A, Loconsole C, et al. Motion detection technology as a tool for cardiopulmonary resuscitation (CPR) quality training: a randomised crossover mannequin pilot study. Resuscitation 2013;84:501-7.

51. Chung TN, Kim SW, You JS, et al. The specific effect of metronome guidance on the quality of one-person cardiopulmonary resuscitation and rescuer fatigue. J Emerg Med 2012;43:1049-54. 